\title{
Transcriptional Regulation of the Urokinase Receptor (u-PAR) - A Central Molecule of Invasion and Metastasis
}

\author{
Tina Fuchs and Heike Allgayer* \\ Department of Surgery, Grosshadern Clinic, \\ Ludwig-Maximilians University of Munich, \\ Marchioninistr. 15, D-81377 Munich, Germany \\ ${ }^{*}$ Corresponding author
}

The phenomenon of tumor-associated proteolysis has been acknowledged as a decisive step in the progression of cancer. This short review focuses on the urokinase receptor (u-PAR), a central molecule involved in tumor-associated invasion and metastasis, and summarizes the transcriptional regulation of u-PAR. The urokinase receptor (u-PAR) is a heavily glycosylated cell surface protein and binds the serine protease urokinase specifically and with high affinity. It consists of three similar cysteine-rich repeats and is anchored to the cell membrane via a GPI-anchor. The u-PAR gene comprises 7 exons and is located on chromosome 19q13. Transcriptional activation of the u-PAR promoter region can be induced by binding of transcription factors (Sp1, AP-1, AP-2, NF-кB). One current study gives an example for transcriptional downregulation of u-PAR through a PEA3/ets transcriptional silencing element. Knowledge of the molecular regulation of this molecule in tumor cells could be very important for diagnosis and therapy in the near future.

Key words: Cancer/Transcription/Tumor-associated proteolysis/u-PAR.

\section{Introduction}

The phenomenon of tumor-associated proteolysis has been acknowledged as a decisive step in cancer progression, invasion and metastasis. One of the proteases which has been implicated in the invasive phenotype of tumor cells is the urokinase-type plasminogen activator (u-PA), a $55 \mathrm{kDa}$ serine protease which, via activation of plasminogen to active plasmin, is able to cleave several components of the extracellular matrix including fibrin, fibronectin, proteoglycans and, as the main molecules in basement membranes, laminin and collagen IV (Duffy, 1992). u-PA interacts with factors often summarized as the plasminogen activator system, consisting of the enzyme (u-PA), one substrate (plasminogen), two receptors
(u-PAR, plasminogen receptor) and three inhibitors (plasminogen activator inhibitors PAl-1 and PAl-2, protease nexin 1) (Blasi, 1993).

Pro-uPA binds to its specific cell surface receptor uPAR specifically and with high affinity and becomes cleaved at position 157 by plasmin, which results in the active two-chain form of u-PA. u-PA can catalyze the activation of ubiquitously available plasminogen to plasmin, which in turn can initiate a proteolytic cascade resulting in a highly efficient degradation of extracellular matrix components (Blasi, 1993).

\section{The U-PAR as a Cell Membrane Receptor with Diverse Functions}

$\mathrm{u}-\mathrm{PAR}$ is a $55-60 \mathrm{kDa}$, heavily glycosylated cell surface receptor with a three-domain structure defined by intrachain disulfide bonds. It consists of three similar cysteine-rich repeats of about 90 amino acids. The aminoterminal domain 1 is responsible for u-PA binding, while the other two domains bind vitronectin (Schvartz et al., 1999). U-PAR is glycosilated at N-residues of glucosamine and sialic acid within the binding site, thereby regulating its affinity $\left(K_{d}\right.$ of $\left.0.1-1.0 \mathrm{~nm}\right)$ for u-PA (Behrendt et al.,1990). The carboxy-terminal part of u-PAR is anchored to the cell membrane via a glycosyl-phosphatidylinositol chain. This GPI-anchor is hypothesized to enable a high intramembrane mobility (Moller, 1993).

The u-PAR plays an important role in many physiological and pathological functions including wound healing, tissue remodeling, and especially tumor cell invasion and metastasis. The ability of the u-PAR to promote these biological effects is a consequence of its diverse functions. First, receptor-bound UPA, as compared to the fluid phase enzyme, activates plasminogen to plasmin much more efficiently, as reflected by a 40 -fold decrease in the $K_{\mathrm{m}}$ value of urokinase for its substrate (Ellis et al., 1991). Plasmin can either directly degrade basement membranes and ECM or activate other proteases. ECM degradation is a key step in the process of cancer invasion. Second, u-PAR clears urokinase-inhibitor complexes from the extracellular space via an $\alpha 2$-macroglobulin receptor-dependent endocytotic mechanism (Cubellis et al., 1990; Conese et al., 1994). Third, the u-PAR interacts with the extracellular domain of integrins (Wei et al., 1996; Yebra et al., 1996). Integrins mediate adhesion of cells to extracellular matrices as well as intercellular inter- 
actions, and modulate transduction of regulatory signals that are central to inflammation, immunity, hemostasis, and tumor progression. u-PAR physically interacts on leukocytes with $\beta 2$-integrin (Bohuslav et al., 1995), and on fibrosarcoma cells with $\beta 1$ - and $\beta 3$-integrins (Xue et al., 1997). Current evidence favors a model in which ligand-induced integrin clustering, a central event in integrin activation, promotes caveolin oligomerization leading to release and/or activation of Src-family kinases and initiation of integrin signaling. The presence of $u-P A R$ promotes these events because the extracellular domain of u-PAR binds to $\beta 1$ - and $\beta 2$-integrins, and the GPI anchor of u-PAR, like that of other GPI-anchored proteins, interacts with cholesterol-rich membrane domains enriched in caveolin and tyrosine kinases (Chapman et al., 1999). Fourth, the u-PAR is chemotactic for human monocytes and mast cells, and this may contribute to inflammatory and tissue remodeling processes, which are also often observed in tumor-infiltrated areas (Resnati et al., 1996; Sillaber et al., 1997).

\section{The Relevance of u-PAR Gene Expression to Invasion and Metastasis}

Numerous studies have shown an overexpression of the u-PAR gene in diverse human malignant tumors in contrast to the corresponding normal tissue and/or surrounding stromal cells (Pyke et al., 1991a,b; Jankun et al., 1993; Morita et al., 1998) and suggested u-PAR as a characteristic of the invasive or even the malignant phenotype (Hollas et al., 1991; Bianchi et al., 1994; Wang et al., 1994). Further studies demonstrated u-PAR and the plasminogen activator system to be strong and independent parameters predicting a poor prognosis of cancer patients (Duffy et al., 1990; Jaenicke et al., 1993) suffering from lung (Pedersen et al., 1994), colon (Mulcahy et al., 1994; Ganesh et al., 1994), esophageal and gastric carninoma (Allgayer et al., 1998; Nekarda et al., 1998). Duffy et al. (2002) showed that breast cancer patients with high u-PA activity in their primary tumors had a shorter disease-free interval than patients with low u-PA activity.

Experimental evidence implicating u-PAR in tumor invasion and metastasis are as follows: overexpression of a human u-PAR cDNA increased the ability of human osteosarcoma cells to penetrate a barrier of reconstituted basement membrane (Kariko et al., 1993). Ossowski (1988) demonstrated that the invasive potential of tumor cells into a chicken embryo chorioallantoic membrane is correlated with u-PAR-associated proteolytic activity. Another study (Kook et al., 1994) revealed that the expression of an antisense u-PAR cDNA in Hep3 squamous carcinoma cells decreased their invasiveness into a modified chorioallantoic membrane. Furthermore, antisense oligonucleotides inhibiting u-PAR gene expression reduced in vitro invasion of transformed human fibroblasts (Quattrone et al., 1995). In glioblastoma, an anti-u-PAR monoclonal antibody effectively blocked matrigel invasion of treated cells (Mohanam et al., 1993). In cultured human lung cancer cell lines, optimum invasiveness was seen only if u-PA, PAl-1 and u-PAR were co-expressed (Liu et al., 1995). High concentrations of PAl-1 also correlate with poor prognosis in patients with breast cancer, including the subgroup with node-negative disease. Possible mechanisms by which PAl-1 contributes to cancer dissemination include modulating cellular adhesion and migration, playing a role in angiogenesis, and stimulating cell proliferation (Duffy et al., 2002). Moreover, Kim et al. (1998) have shown elegantly that the expression of the uPAR gene by tumor cells, besides u-PA and MMP-9, is required for the intravasation of blood vessels. Min et al. (1996) reported that U-PAR antagonists prevent tumor growth and angiogenesis, suggesting that u-PAR gene expression is important for tumor and metastasis establishment and outgrowth. Finally, Lakka et al. (2001) reported that the transfection of an adenovirus construct (Ad-uPAR) in non-small cell lung cancer cell lines with high levels of u-PAR resulted in a decrease of u-PAR levels by $80-90 \%$, leading to a reduction of invasion and metastasis. Taken together, all of these studies suggest u-PAR as a critical molecule for invasion, intravasation, and metastasis.

\section{Transcriptional Activation of u-PAR Gene Expression}

The objective to counter u-PAR gene expression in malignant tumors necessarily implies the question as to how it is regulated. The mechanisms of regulation and causes for an upregulation of u-PAR in malignant cells are still the objectives of intensive investigations. Although altered mRNA stability and receptor recycling may be involved, the amounts of u-PAR are controlled mainly at the transcriptional level in malignancies such as colon cancer (Lund et al., 1995; Lengyel et al., 1996; Shetty et al., 1997; Gum et al., 1998). Altered transcription of the gene is the main mediator of u-PAR gene expression brought about by, for example, epidermal growth factor (EGF; Boyd, 1989), basic fibroblast growth factor (FGF; Mignatti et al., 1991), vascular endothelial growth factor (VEGF; Mandriota et al., 1995), transforming growth factor $\beta$ type 1 (TGF- $\beta 1$; Lund et al., 1995), phorbol 12-myristate 13-acetate (PMA; Lengyel et al., 1996), IFN- $\alpha$ or IFN- $\gamma$, (Wu et al., 2002), protein kinase C (PKC; Ando et al., 1996), protein kinase A (PKA)/C-AMP (Langer et al., 1993; Li et al., 1995), the MAPK- (Lengyel et al., 1997) and the JNK-pathway (Gum et al., 1998).

The u-PAR gene spans seven exons and is located on chromosome 19q13 (Borglum et al., 1992). Transcription of the gene yields a $1.4 \mathrm{~kb}$ mRNA or an alternatively spliced variant lacking the membrane attachment peptide sequence (Roldan et al., 1990; Pyke et al., 1993). The human u-PAR promoter sequence was first described by Wang et al. (1995) and Soravia et al. (1995). Like classic 


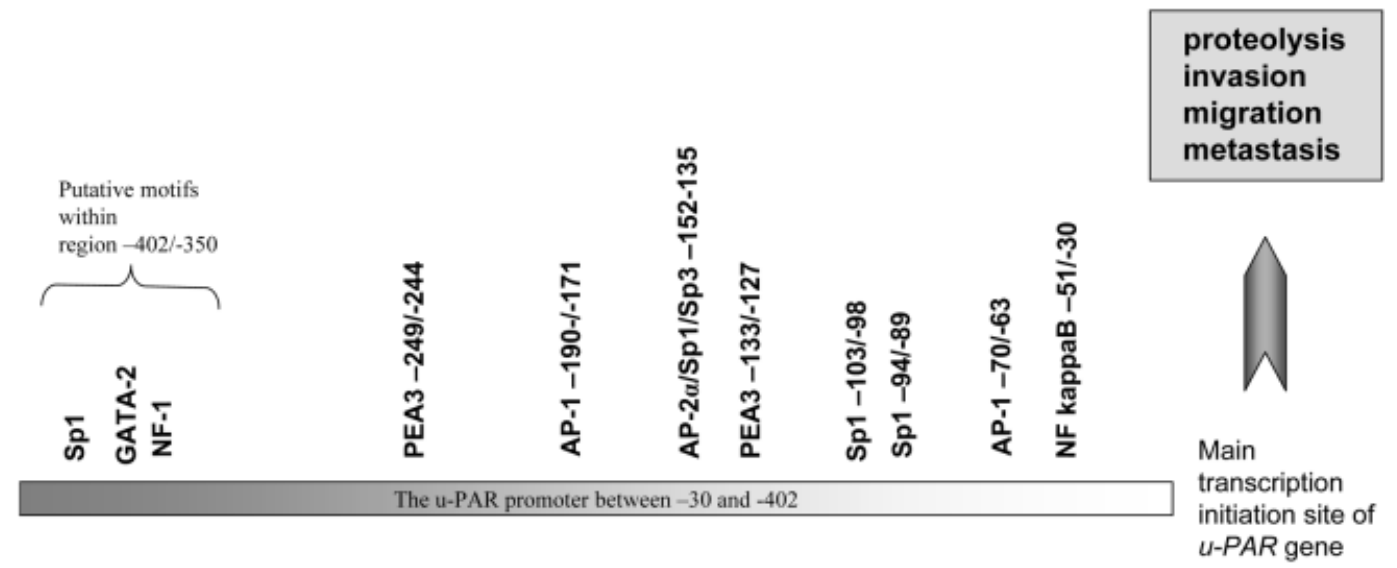

Fig. 1 Overview of Potential Promoter Elements Regulating u-PAR Gene Expression.

'housekeeping genes', it lacks TATA and CAAT boxes and contains a GC-rich proximal sequence with multiple Sp1 consensus elements. Using primer extension analysis, Soravia et al. (1995) reported three transcriptional start sites, the most upstream of which - an A following a C appeared to be the main transcription initiation site and revealed partial similarity to the consensus initiator sequence of the dihydrofolate reductase (DHFR) gene (Means et al., 1990; Soravia et al., 1995). The most proximal 135 base pairs of the human U-PAR promoter showed $68 \%$ similarity to the murine u-PAR promoter (Suh et al., 1994).

An overview on the current status on putative or experimentally validated promoter elements regulating the u-PAR gene is given in Figure 1 .

First reports of Soravia et al. (1995) suggested that the basal expression of the gene is regulated via Sp1 motifs proximal and upstream of the transcriptional start site. In colon cancer, both the constitutive and PMA-inducible expression of the gene required a footprinted region located at basepairs $-190 /-171$ of the promoter containing an AP-1 consensus motif bound by Jun-D, c-Jun, c-Fos and Fra-1 (Lengyel et al., 1996). This motif also mediates the induction of u-PAR gene expression via the MAPKand the JNK-pathway (Lengyel et al., 1997; Gum et al., 1998).

This AP-1 consensus motif is also required for induction of u-PAR gene expression brought about by the K-ras oncogene (Allgayer et al., 1999). A substantial reduction of endogenous u-PAR protein and u-PAR-mediated proteolysis was observed in HCT116 clones in which activated K-ras had been deleted. In gelshift and CAT-reporter analysis we detected a decrease of the binding of c-Jun, JunD, c-Fos and Fra-1 in the K-rasknockout clones, and this was paralleled by a severe reduction of promoter activity when the AP-1-consensus motif within promoter region -190/-171 was deleted. These results suggest that activated $\mathrm{K}$-ras regulates u-PAR and u-PAR-mediated proteolysis in colon cancer, at least in part via the $-190 /-171$ region of the promoter bound by AP-1-transcription factors.
Ras uses a variety of functionally diverse effectors that transduce signals through multiple pathways. The binding of effector proteins involves at least interactions with the effector loop (amino acids 32-40) of Ras. The use of multiple effector pathways by Ras has been demonstrated through the use of constitutively activated mutants of Ras with point mutations in the effector domain. Muller et al. (2000) showed that constitutively active V12 H-Ras and Rho-A lead to an increased transcription from the uPAR promoter. Thereby the use of Ras-effector-loop mutants indicated that signaling via multiple Ras effectors is necessary for the maximum activation of u-PAR transcription. Okan et al. (2001) further showed that a constitutively activated RalA mutant (RalA 72L) stimulates uPAR transcription. RalA is one of two highly similar (85\% identity) GTPases of the Ras subfamily. The stimulation of u-PAR transcription required the presence of the ATF2like AP-1 site at $70 \mathrm{bp}$ and the c-Jun binding motif at $184 \mathrm{bp}$ upstream of the major transcriptional start site. Activation of transcription is inhibited by a dominantnegative mutant of $\mathrm{c}-\mathrm{Src}$, indicating that $\mathrm{C}-\mathrm{Src}$ is a downstream effector of RalA. These data showed activation of u-PAR trancription by RalA through an AP-1-dependent mechanism.

Another footprinted region (-148/-124) of the u-PARpromoter containing putative binding sites for (mismatched) Sp1, AP-2 and PEA3 binding motifs (Lengyel et al., 1996) was shown to be bound by an AP-2 $\alpha$-like protein closely related to, but not identical with, authentic $\mathrm{AP}-2 \alpha, \mathrm{Sp} 1$ and Sp3 transcription factors. The region required for binding were identified as $-152 /-135$ (Allgayer et al., 1999a). Binding of the AP- $2 \alpha$-like protein was found to be important for a constitutively high u-PAR promoter activity in a highly invasive colon cancer cell line and for PMA-stimulated u-PAR expression in a cell line with low constitutive u-PAR expression. Interestingly, a dominant-negative AP-2 expression construct not only reduced $u-P A R$ promoter activity and u-PAR gene expression but also substantially inhibited u-PAR-mediated proteolysis. These results suggest that an inhibition at the transcriptional level can be used to suppress u-PAR-me- 
diated proteolysis, thereby potentially inhibiting invasion and metastasis.

The binding of Sp1 transcription factor to region -152/135 of the u-PAR promoter was shown to be important in part for PMA-induced u-PAR promoter activity, but, more interestingly, for the induction of u-PAR gene expression by the c-src oncogene in colon cancer (Allgayer et al., 1999b). In SW480 colon cancer clones stably expressing a constitutively active Src (Y-C-src527F), increased uPAR protein and laminin degradation paralleling elevated Src activity was evident as compared to parental cells. Nuclear run-on experiments indicated that the increased u-PAR protein was due largely to transcriptional activation. While transient transfection of SW480 cells with Y-c-src527F induced a u-PAR-CAT-reporter, mutations preventing Sp1-binding to promoter region -152/-135 abolished this induction. Mobility shift assays revealed increased Sp1 binding to region -152/-135 with nuclear extracts of Src-transfected SW480 cells. Finally, the amounts of endogenous u-PAR in resected colon cancers significantly correlated with Src-activity. These data suggest that u-PAR gene expression and u-PAR-mediated proteolysis are regulated by $\mathrm{Src}$, which requires the promoter region (-152/-135) bound by Sp1, thus demonstrating for the first time that transcription factor $\mathrm{Sp} 1$ is a downstream effector of Src.

The transcription factor NF- $\mathrm{KB}$ has also been implicated in the regulation of the u-PAR. In a recent study, Wang et al. (2000) implicated NF-KB bound to a non-consensus NF- $\kappa B$ motif $(-51 /-30)$ in the constitutive expression of the u-PAR gene in HCT116 colon cancer cells. Co-transfection with a dominant-negative IKB-kinase-2 expression vector reduced u-PAR promoter activity up to $75 \%$, demonstrating that this region is required for promoter activity.

\section{Transcriptional Downregulation of u-PAR}

Although many reports showed a transcriptional activation of u-PAR gene expression by diverse promoter motifs, there is not much known about potential silencer elements. One example for transcriptional suppression has been given by Hapke et al. (2001), indicating a PEA3-element at $-248 \mathrm{bp}$ as a mediator of integrin-induced suppression: the adhesion receptor $\beta 3$-integrin downregulated $\mathrm{u}$-PAR in $\mathrm{CHO}$ cells, an overexpression of $\beta 3$-integrin leading to a reduction of u-PAR mRNA and u-PAR promoter activity. Downregulation of u-PAR expression can be increased by clustering of $\alpha v \beta 3$-integrin, which was achieved after ligation with immobilized vitronectin or the antibody LM609. After transient transfection, a CAT reporter driven by 398 bp of 5'-flanking sequence of the uPAR promoter was significantly reduced by a $\beta 3$-integrin expression construct, whereas transfection of $\alpha v$-integrin alone did not show any effect on the u-PAR promoter. This indicated that the $\mathrm{u}$-PAR promoter contains a transcription factor binding site that might account for a $\beta 3$-integrin-mediated repression of u-PAR gene transcription in $\mathrm{CHO}$ cells. Using 5'-deletion fragments of the u-PAR promoter and the $\beta 3$-integrin expression vector, a sequence between -398 and -197 bp of the u-PAR promoter was identified to be essential for $\beta 3$-integrin-mediated u-PAR gene suppression. Deletion of the PEA3/ets motif at position -248 prevented the ability of $\beta 3$-integrin to downregulate the u-PAR promoter. Furthermore, an expression vector encoding PEA3 inhibited the activity of the wild type but not the activity of the mutated form. In $\beta 3$-integrin-overexpressing cells, nuclear factors showed enhanced binding activity for the PEA3/ets site and PEA3 was identified by an anti-PEA3 antibody which inhibited DNA-protein complex formation. These experiments suggest a PEA3/ets motif at $-248 \mathrm{bp}$ as a transcriptional repressor of the u-PAR gene (Hapke et al., 2001).

Recently, a new tumor suppressor gene (pdcd4) inhibiting neoplastic transformation of epithelial cells has been identified, however, its role in invasion and mechanisms of regulation has not been investigated yet (Cmarik et al., 1999; Hsu et al., 2000; Yang et al., 2001). Preliminary studies of our group implicate that Pdcd4 might downregulate u-PAR gene expression at least in part by inhibiting u-PAR gene transcription, and a region containing putative binding sites for Sp-1, GATA-2 and NF-1 (-402/-350 bp), but also the PEA3/ets motif at -248 bp might be mediators of this suppression (Leupold et al., 2002)

\section{Conclusion}

In summary, the u-PAR is a central molecule of invasion and metastasis with clinical-prognostic value that has been shown to be regulated especially at the transcriptional level by diverse cis-elements and trans-acting factors. These mediate multiple means of induction or suppression by different regulators involving, for example, signaling cascades, oncogenes, or even potentially tumor suppressor genes. When speculating about developing future therapeutic strategies based on this knowledge, it is interesting to hypothesize that, besides already existing u-PAR-inhibitory strategies at the protein level (antibodies, small molecular compounds; Wilhelm et al., 1994; Renatus et al., 1998; Aguirre-Ghiso et al., 1999) or efforts to inhibit at the signal transduction level (e.g. MAPK-, Src- and K-Ras-inhibition) even a direct targeting of transcriptional mechanisms could be considered.

To support this notion, in a first clinical study comparing transcription factor binding to u-PAR promoter region $-152 /-135$ in 145 patients with resected colorectal or gastric cancers in primary tumors and corresponding normal mucosae, we suggested a tumor-specific transactivation of u-PAR gene expression by this promoter region in about $60 \%$ of cases (Schewe et al., 2001). Therefore, it might be possible in the future to identify subgroups of patients where a targeting of certain promoter regions with a preference for tumor cells could be speculated. It 
should be attractive to further develop targeting methods such as triplex binding oligonucleotides which might be appropriate to be applied as targeting tools at the transcriptional level.

Ultimately, there is to be expected an exciting development in next few years to extend the knowledge on uPAR and its regulators as molecular markers to improve the prediction of an individual patient's clinical outcome, define approaches in the treatment of cancer invasion and metastasis, and define appropiate target subpopulations of patients.

\section{Acknowledgments}

H.A. is supported by grants from the Deutsche Krebshilfe, Bonn, Germany, the Wilhelm Sander Stiftung, the Faculty of Medicine of the Ludwig-Maximilians-University of Munich, the MMWBoard of Editors, Munich, Germany, the Friedrich Baur Stiftung, Munich, Germany, and the Graute-Oppermann-Stiftung, Lüdenscheid, Germany. We thank Andreas Orth for excellent help with the manuscript.

\section{References}

Aguirre-Ghiso, J.A., Kovalski, K., and Ossowski, L. (1999). Tumor dormancy induced by downregulation of urokinase receptor in human carcinoma involves integrin-mediated adhesion and signaling. J. Cell. Biol. 144, 1285-1294.

Allgayer, H., Wang, H., Gallick, G.E., Crabtree, A., Mazar, A., Jones, T., Kraker, A.J., and Boyd D.D. (1999). Transcriptional induction of the urokinase-receptor (u-PAR) gene by a constitutively active Src: requirement of an upstream motif (-152/-135) bound with Sp1. J. Biol. Chem. 274, 18428-18437.

Allgayer, H., Wang, H., Shirasawa, S., Sasazuki, T., and Boyd D.D. (1999). Targeted disruption of K-ras oncogene in an invasive cancer cell line down-regulates urokinase receptor expression and plasminogen-dependent proteolysis. Br. J. Cancer 80, $1884-1891$.

Allgayer, H., Wang, H., Wang, Y., Heiss, M.M., Bauer, R., Nyormoi, O., and Boyd, D.D. (1999). Transactivation of the urokinase-type plasminogen activator receptor gene through a novel promoter motif bound with an activator-protein-2 $\alpha$-related factor. J. Biol. Chem. 274, 4702-4714.

Allgayer, H., Heiss, M.M., and Schildberg, F.W. (1997). Prognostic factors in gastric cancer: a review. $\mathrm{Br}$. J. Surgery 84 , 1651-1664.

Ando, Y., and Jensen, P J. (1996). Protein kinase C mediates upregulation of urokinase and its receptor in the migrating keratinocytes of wounded cultures, but urokinase is not required for movement across a substratum in vitro. J. Cell Physiol. 167, 500-511.

Behrendt, N., Ronne, E., Ploug, M., Petri, T., Lober, D., Nielsen, L.S., Schleunig, W.D., Blasi, F., Appella, E., and Dano, K. (1990). The human receptor for urokinase plasminogen activator. $\mathrm{NH}_{2}$-terminal amino acid sequence and glycosylation variants. J. Biol. Chem. 265, 6453-6460.

Bianchi, E., Cohen, R.L., Thor, A.T., Mizukami, I.F., Lawrence, D.A., Ljung, B.M., Shuman, M.A., and Smith, H.S. (1994). The urokinase receptor is expressed in invasive breast cancer but not in normal breast tissue. Cancer Res. 54, 861-866.

Blasi, F. (1993). Urokinase and urokinase receptor: a paracrine/autocrine system regulating cell migration and invasiveness. Bioessays 15, 105-111.
Bohuslav, J., Horejsi, V., Hansmann, C., Stockl, J., Weidle, U.H., Majdic, O., Bartke, I., Knapp, W., and Stockinger, H. (1995). Urokinase plasminogen activator receptor, $\beta 2$-integrins, and src-kinases within a single receptor complex of human monocytes. J. Exp. Med. 181, 1381-1390.

Borglum, A.D., Byskov, A., Ragno, P., Roldan, A.L., Tripputi, P., Cassani, G., Dano, K., Blasi, F., Bolund, L., and Kruse, T.A. (1992). Assignment of the urokinase-type plasminogen activator receptor gene (PLAUR) to chromosome 19q13.1-q13.2. Am. J. Hum. Genet. 50, 492-497.

Boyd, D. (1989). Examination of the effects of epidermal growth factor on the production of urokinase and the expression of the plasminogen activator receptor in a human colon cancer cell line. Cancer Res. 49, 2427 -2432.

Chapman, H.A., Wei, Y., Simon, D.I., and Waltz, D.A. (1999). Role of urokinase receptor and caveolin in regulation of integrin signaling. Thromb. Haemost. 82, 291-297.

Cmarik, J.L., Min, H., Hegamyer, G., Zhan, S., Kulesz-Martin, M., Yoshinaga, H., Matsuhashi, S., and Colburn, N.H. (1999). Differentially expressed protein Pdcd4 inhibits tumor promoterinduced neoplastic transformation. Proc. Natl. Acad. Sci. USA 96, $14037-14042$.

Conese, M., Olson, D., and Blasi, F.A.D. (1994). Protease nexin1-urokinase complexes are internalized and degraded through a mechanism that requires both urokinase receptor and $\alpha 2-$ macroglobulin receptor. J. Biol. Chem. 269, 17886-17892.

Cubellis, M.V., Wun, T.C., and Blasi, F. (1990). Receptor-mediated internalization and degradation of urokinase is caused by its specific inhibitor PAl-1. EMBO J. 9, 1079-1085.

Duffy, M.J. (1992). The role of proteolytic enzymes in cancer invasion and metastasis. Clin. Exp. Metastasis 10, 145-155.

Duffy, M.J. (2002). Urokinase plasminogen activator and its inhibitor, PAl-1, as prognostic markers in breast cancer: from pilot to level 1. Evidence Studies. Clin. Chem. 48, 1194-1197.

Duffy, M.J., Reilly, D., O’Sullivan, C., O'Higgins, N., Fennelly, J.J., and Andreasen, P. (1990). Urokinase plasminogen activator, a new and independent prognostic marker in breast cancer. Cancer Res. 50, 6827-6829.

Ellis, V., Behrendt, N., and Dano, K. (1991). Plasminogen activation by receptor-bound urokinase. J. Biol. Chem. 266, $12752-12758$.

Ganesh, S., Sier, C.F.M., Heerding, M.M., Griffionen, G., Lamers, C.B.H., and Vespaget, H. W. (1994). Urokinase receptor and colorectal cancer survival. Lancet 344, 401-402.

Gum, R., Juarez, J., Allgayer, H., Mazar, A., Wang, Y., and Boyd, D. (1998). Stimulation of urokinase-type plasminogen activator receptor expression by PMA requires a JNK1-dependent signaling module. Oncogene 17, 213-225.

Hapke, S., Gawaz, M., Dehne, K., Köhler, J., Marshall, J.F., Graeff, H., Schmitt, M., Reuning, U., and Lengyel, E. (2001). ß3AIntegrin downregulates the urokinase-type plasminogen activator receptor (u-PAR) through a PEA3/ets transcriptional silencing element in the u-PAR promoter. Mol. Cell Biol. 6, 2118-2132.

Hollas, W., Blasi, F., and Boyd, D. (1991). Role of the urokinase receptor in facilitating extracellular matrix invasion by cultured colon cancer. Cancer Res. 51, 3690-3695.

Hsu, T.C., Young, M.R., Cmarik, J., and Colburn, N.H. (2000). Activator protein 1 (AP-1) and nuclear factor $\mathrm{kB}$-dependent transcriptional events in carcinogenesis. Free Radic. Biol. Med. 28, $1338-1348$.

Jänicke, F., Schmitt, M., Pache, L., Ulm, K., Harbeck, N., Hoefler, H., and Graeff, H. (1993). Urokinase (UPA) and its inhibitor PAl-1 are strong and independent prognostic factors in node negative breast cancer. Breast Cancer Res. Treatment 24, 195-208. 
Jankun, J., Merrick, H.W., and Goldblatt, P.J. (1993). Expression and localization of elements of the plasminogen activation system in benign breast disease and breast cancers. J. Cell Biochem. 53, 135-144.

Kariko, K., Kuo, A., Boyd, D., Okada, S., Cines, D., and Barnathan, E. (1993). Overexpression of urokinase receptorincreases matrix invasion without altering cell migration in a human osteosarcoma cell line. Cancer Res. 53, 3109-3117.

Kim, J., Yu, W., Kovalski, K., and Ossowski, L. (1998). Requirement for specific proteases in cancer cell intravasation as revealed by a novel semiquantitative PCR-based assay. Cell 94, 353-362.

Kook, Y.H., Adamski, J., Zelent, A., and Ossowski, L. (1994). The effect of antisense inhibition of urokinase receptor in human squamous cell carcinoma on malignancy. EMBO J. 13, $3983-3991$.

Lakka, S.S., Rajagopal, R., Rajan, M.K., Mohan, P.M., Adachi, Y., Dinh, D.H., Olivero, W.C., Gujrat, M., Ali-Osman, F., Roth, J.A. et al. (2001). Adenovirus-mediated antisense urokinase-type plasminogen activator receptor gene transfer reduces tumor cell invasion and metastasis in non-small cell lung cancer cell lines. Clin. Cancer Res. 7, 1087-1093.

Langer, D.J., Kuo, A., Kariko, K., Ahuja, M., Klugherz, B.D., Ivanics, K.M., Hoxie, J.A., William, W.V., Liang, B.T., Cines, D.B, and Barnathan, E.S. (1993). Regulation of the endothelial cell urokinase-type plasminogen activator receptor - evidence for cyclic AMP-dependent and protein kinase C-dependent pathways. Circulation Res. 72, 330-340.

Lengyel, E., Wang, H., Stepp, E., Juarez, J., Doe, W., Pfarr, C.M., and Boyd, D. (1996). Requirement of an upstream AP-1 motif for the constitutive and phorbol ester-inducible expression of the urokinase-type plasminogen activator receptor gene. J. Biol. Chem. 271, 23176-23184.

Lengyel, E., Wang, H., Gum, R., Simon, C., Wang, Y., and Boyd, D. (1997). Elevated urokinase-type plasminogen activator receptor expression in a colon cancer cell line is due to a constitutively activated extracellular signal-regulated kinase-1. dependent signaling cascade. Oncogene 14, 2563-2573.

Leupold, J.H., Colburn, N.H., Yang, H.S., Lengyel, E., Schildberg, F.W., Heiss, M.M., and Allgayer, H. (2002). First evidence for the new tumor suppressor Pdcd4 as a regulator of u-PAR, an invasion-related gene. Proc. Am. Assoc. Cancer Res. 43, 622.

Li, C., Liu, J.N., and Gurewich, V. (1995). Urokinase-type plasminogen activator-induced monocyte adhesion requires a carboxyl-terminal lysine and cAMP-dependent signal transduction. J. Biol. Chem. 270, 30282-30285.

Liu, G., Shuman, M.A., and Cohen, R.L. (1995). Co-expression of urokinase, urokinase receptor and PAI 1 is necessary for optimum invasiveness of cultured lung cancer cells. Int. J. Cancer 60, 501-506.

Lund, L.R., Ellis, V., Ronne, E., Pyke, C., and Dano, K. (1995). Transcriptional and post-transcriptional regulation of the receptor for urokinase-type plasminogen activator by cytokines and tumor promoters in the human lung carcinoma cell line A549. Biochem. J. 310, 345-352.

Mandriota, S.J., Seghezzi, G., Vassalli, J.D., Ferrara, N., Wasi, S., Mazzieri, R., Mignatti, P., and Pepper, M.S. (1995). Vascular endothelial growth factor increases urokinase receptor expression in vascular endothelial cells. J. Biol. Chem. 270, 9709-9716.

Means, A.L., and Farnham, P.J. (1990). Transcription initiation from the dihydrofolate reductase promoter is positioned by HIP1 binding at the initiation site. Mol. Cell Biol. 10, 653-661.

Mignatti, P., Mazzieri, R., and Rifkin, D.B. (1991). Expression of the urokinase receptor in vascular endothelial cells is stimulat- ed by basic fibroblast growth factor. J. Cell Biol. 113, 1193-1201.

Min, H.Y., Doyle, L.V., Vitt, C.R., Zandonella, C.L., StrattonThomas, J.R., Shuman, M.A., and Rosenberg, S. (1996). Urokinase receptor antagonists inhibit angiogenesis and primary tumor growth in syngeneic mice. Cancer Res. 56, $2428-2433$.

Mohanam, S., Sawaya, R., McCutcheon, I., Ali-Oshman, F., Boyd, D., and Rao, J.S. (1993). Modulation of in vitro invasion of human glioblastoma cells by urokinase-type plasminogen activator receptor antibody. Cancer Res. 53, 4143-4147.

Moller, L.B. (1993). Structure and function of the urokinase receptor. Blood Coagul. Fibrinol. 4, 293-303.

Morita, S., Sato, A., Hayakawa, H., Ihara, H., Urano, T., Takada, Y., and Takada, A. (1998). Cancer cells overexpress mRNA of urokinase-type plasminogen activator, its receptor, and inhibitors in human non-small cell lung cancer tissue: analysis by Northern blotting and in situ hybridization. Int. J. Cancer 78, 286-292.

Mulcahy, H.E., Duffy, M.J., Gibbons, D., McCarthy, P., Parfrey, N.A., O'Donoghue, D.P., and Sheahan, K. (1994). Urokinasetype plasminogen activator and outcome in Dukes' B colorectal cancer. Lancet 344, 583-584.

Muller, S.M., Okan, E., and Jones, P. (2000). Regulation of urokinase receptor transcription by Ras- and Rho-family GTPases. Biochem. Biophys. Res. Commun. 270, 892-898.

Nekarda, H., Schlegel, P., Schmitt, M., Stark, M., Mueller, J.D., Fink, U., and Siewert, J.R. (1998). Strong prognostic impact of tumor-associated urokinase-type plasminogen activator in completely resected adenocarcinoma of the esophagus. Clin. Cancer Res. 4, 1755-1763.

Okan, E., Drewett, V., Shaw, P.E., and Jones, P. (2001). The small-GTPase RalA activates transcription of the urokinase plasminogen activator receptor (u-PAR) gene via an AP1-dependent mechanism. Oncogene 15, 1816-1824.

Ossowski, L. (1988). In vivo invasion of modified chorioallantoic membrane by tumor cells: the role of cell surface-bound urokinase. J. Cell Biol. 107, 2427-2445.

Pedersen, H., Grondahl-Hansen, J., Francis, D., Osterlind, K., Hansen, H. H., Dano, K., and Brünner, N. (1994). Urokinase and plasminogen activator inhibitor type 1 in pulmonary adenocarcinoma. Cancer Res. 54, 120-123.

Pyke, C., Kristensen, P., Ralfkiaer, E., Eriksen, J., and Dano, K. (1991a). The plasminogen activation system in human colon cancer: Messenger RNA for the inhibitor PAl-1 is located in endothelial cells in the tumor stroma. Cancer Res. 51, 4067-4071.

Pyke, C., Kristensen, P., Ralfkiaer, E., Grondahl-Hansen, J., Eriksen, J., Blasi, F., and Dano, K. (1991b). Urokinase-type plasminogen activator is expressed in stromal cells and its receptor in cancer cells at invasive foci in human colon adenocarcinomas. Am. J. Pathol. 138, 1059-1067.

Pyke, C., Eriksen, J., Solberg, H., Schnack, B., Nielsen, S., Kristensen, P., Lund, L.R., and Dano, K. (1993). An alternatively spliced variant of mRNA for the human receptor for urokinase plasminogen activator. FEBS Lett. 326, 69-74.

Quattrone, A., Fibbi, G., Anichini, E., Pucci, M., Zamperini, A., Capaccioli, S., and DelRosso, M.D. (1995). Reversion of the invasive phenotype of transformed human fibroblasts by antimessenger oligonucleotide inhibition of urokinase receptor gene expression. Cancer Res. 55, 90-95.

Renatus, M., Bode, W., Huber, R., Sturzebecher, J., and Stubbs, M.T. (1998). Structural and functional analyses of benzamidine-based inhibitors in complex with trypsin: implications for the inhibition of factor Xa, tPA, and urokinase. J. Med. Chem. $41,5445-5456$. 
Resnati, M., Gutringer, M., Valcamonica, S., Sidenius, N., Blasi, F., and Fazioli, F. (1996). Proteolytic cleavage of the urokinse receptor substitutes for the agonist-induced chemotactic effect. EMBO J. 15, 1572-1582.

Roldan, A., Cubellis, M., Masucci, M., Behrendt, N., Lund, L., Dano, K., Appella, E., and Blasi, F. (1990). Cloning and expression of the receptor for human urokinase plasminogen activator, a central molecule in plasmin-dependent proteolysis. EMBO J. 9, 467-474.

Schewe, D., Heiss, M.M., Boyd, D.D., Wang, H., Lengyel, E., Hornung, H.M., Grützner, K.U., Schildberg, F.W., and Allgayer H. (2001). Transcription factor binding to region $-152 /-135$ of the urokinase receptor (U-PAR) gene: first analysis of a clinical relevance in gastrointestinal carcinomas. Proc. Am. Assoc. Cancer Res. 42, 618.

Schvartz, I., Seger, D., and Shaltiel, S. (1999). Vitronectin. Int. J. Biochem. Cell Biol. 31, 539-544.

Shetty, S., Kumar, A., and Idell, S. (1997). Posttranscriptional regulation of urokinase receptor mRNA: identification of a novel urokinase receptor mRNA binding protein in human mesothelioma cells. Mol. Cell Biol. 17, 1075-1083.

Sillaber, C., Baghestanian, M., Hofbauer, R., Virgolini, I., Bankl, H.C., Fureder, W., Agis, H., Willheim, M., Leimer, M., Scheiner, O. et al. (1997). Molecular and functional characterization of the urokinase receptor on human mast cells. J. Biol. Chem. 272, 7824-7832.

Sliva, D., English, D., Lyons, D., and Lloyd, F.P. (2002). Protein kinase $C$ induces motility of breast cancers by upregulating secretion of urokinase-type plasminogen activator through activation of AP-1 and NF-KB. Biochem. Biophys. Res. Commun. $290,552-557$.

Soravia, E., Grebe, A., De Luca, P., Helin, K., Suh, T.T., and Degen, J.L. (1995). A conserved TATA-less proximal promoter drives basal transcription from the urokinase-plasminogen activator receptor gene. Blood 86, 624-635.

Suh, T., Nerlov, K., Dano, K., and Degen, J.L. (1994). The murine urokinase-type plasminogen activator receptor gene. J. Biol. Chem. 269, 25992-25998.
Wang, H., Skibber, J., Juarez, J., and Boyd, D. (1994). Transcriptional activation of the urokinase receptor gene in invasive colon cancer. Int. J. Cancer 58, 650-657.

Wang, Y., Dang, J., Wang, H., Allgayer, H., Murrell, G.A.C., and Boyd, D. (2000). Identification of a novel nuclear factor- $\kappa B$ sequence involved in expression of urokinase-type plasminogen activator receptor. Eur. J. Biochem. 267, 3248-3254.

Wang, Y., Dand, J., Johnson, L.K., Selhamer, J.J., and Doe, W.F. (1995). Structure of the human urokinase receptor gene and its similarity to CD59 and the Ly-6 family. Eur. J. Biochem. 227, $116-122$.

Wei, Y., Lukashev, M., Simon, D. I., Bodary, S. C., Rosenberg, S., Doyle, M. V., and Chapman, H.A. (1996). Regulation of integrin function by the urokinase receptor. Science 273, 15511555.

Wilhelm, O., Weidle, U., Höhl, S., Rettenberger, P., Schmitt, M., and Graeff, H. (1994). Recombinant soluble urokinase receptor as a scavenger for urokinase-type plasminogen activator (UPA). Inhibition of proliferation and invasion of human ovarian cancer cells. FEBS Lett. 337, 131-134.

Wu, S., Murrell, G.A.C., and Wang, Y. (2002). Interferon- $\alpha$ (Intron A) upregulates urokinase-type plasminogen activator receptor gene expression. Cancer Immunol. Immunother. 51, 248254.

Xue, W., Mizukami, I., Todd, R.F., and Petty, H.R. (1997). Urokinase-type plasminogen activator receptors associate with $\beta 1$ and $\beta 3$-integrins of fibrosarcoma cells: dependence on extracellular matrix components. Cancer Res. 57, 1682-1689.

Yang, H.S., Jansen, A.P., Nair, R., Shibahara, K., Verma, A.K., Cmarik, J.L., and Colburn, N.H. (2001). A novel transformation suppressor, Pdcd4, inhibits AP-1 transactivation but not NFКB or ODC transactivation. Oncogene 20, 669-676.

Yebra, M., Parry, G.C.N., Stromblad, S., Machman, N., Rosenberg, S., Mueller, B.M., and Cheresh, D.A. (1996). Requirement of receptor-bound urokinase-type plasminogen activator for integrin $\alpha v \beta 5$-directed cell migration. J. Biol. Chem. 271, 29393-29399. 